\title{
Altered synaptic structure in the hippocampus in a mouse model of Alzheimer's disease with soluble amyloid- $\beta$ oligomers and no plaque pathology
}

Katherine A Price ${ }^{1,2}$, Merina Varghese ${ }^{1,2}$, Allison Sowa ${ }^{1,2}$, Frank Yuk ${ }^{1,2}$, Hannah Brautigam ${ }^{2,3}$, Michelle E Ehrlich ${ }^{2,3,4}$ and Dara L Dickstein ${ }^{1,2^{*}}$

\begin{abstract}
Background: Mounting evidence suggests that soluble oligomers of amyloid- $\beta$ (oA $\beta$ ) represent the pertinent synaptotoxic form of $A \beta$ in sporadic Alzheimer's disease (AD); however, the mechanistic links between oA $\beta$ and synaptic degeneration remain elusive. Most in vivo experiments to date have been limited to examining the toxicity of $\mathrm{OA} \beta$ in mouse models that also possess insoluble fibrillar $A \beta(f A \beta)$, and data generated from these models can lead to ambiguous interpretations. Our goal in the present study was to examine the effects of soluble oA $\beta$ on neuronal and synaptic structure in the amyloid precursor protein (APP) E693Q ("Dutch") mouse model of AD, which develops intraneuronal accumulation of soluble oA $\beta$ with no detectable plaques in AD-relevant brain regions. We performed quantitative analyses of neuronal pathology, including dendrite morphology, spine density, and synapse ultrastructure in individual hippocampal CA1 neurons.

Results: When assessing neuronal morphology and complexity we observed significant alterations in apical but not in basal dendritic arbor length in Dutch mice compared to wild type. Moreover, Dutch mice exhibited a significant decrease in dendritic arborization with a decrease in dendritic length and number of intersections at $120 \mu \mathrm{m}$ and $150 \mu \mathrm{m}$ from the soma, respectively. We next examined synaptic parameters and found that while there were no differences in overall synaptic structure, Dutch mice displayed a significant reduction in the post-synaptic density (PSD) length of synapses on mushroom spines, in comparison to wild type littermates.

Conclusion: The structural alterations to individual neurons in Dutch mice along with the changes in larger dendritic spines support the $A \beta$ oligomer hypothesis, which postulates that the early cognitive impairments that occur in $A D$ are attributed to the accumulation of soluble $O A \beta$ first affecting at the synaptic level with subsequent structural disturbances and cellular degeneration.
\end{abstract}

Keywords: Alzheimer's disease, Aß oligomers, Neuron, APP E693Q, Synapse, Postsynaptic density, Dendrite, Spines

\footnotetext{
* Correspondence: dara.dickstein@mssm.edu

${ }^{1}$ Fishberg Department of Neuroscience, Icahn School of Medicine at Mount

Sinai, One Gustave L. Levy Place, Box 1639, New York, NY 10029, USA

${ }^{2}$ Friedman Brain Institute, Icahn School of Medicine at Mount Sinai, New

York, NY 10029, USA

Full list of author information is available at the end of the article
} 


\section{Background}

The neuropathological hallmarks of Alzheimer's disease $(\mathrm{AD})$ include amyloid- $\beta(\mathrm{A} \beta)$ plaque accumulation, neurofibrillary tangle formation, and synaptic and neuronal loss. How these factors ultimately contribute to memory loss and cognitive deficits that clinically characterize the disease remains unclear. In $\mathrm{AD}$ brains, $\mathrm{A} \beta$ can spontaneously aggregate and thereby assume a variety of conformational states ranging from monomers to soluble oligomers, protofibrils, and insoluble fibrils, which assemble to form extracellular plaques $[1,2]$. Further characterization of this array of $\mathrm{A} \beta$ conformations has proven critical for deciphering which of these may be neurotoxic. The insoluble fibrillar $A \beta(f A \beta)$ found in the extracellular plaques in post-mortem $\mathrm{AD}$ brains has long been postulated as the initiating agent in the neurodegenerative cascade of the disease. However, many recent studies have demonstrated that the amount and distribution of amyloid plaques does not correlate with synaptic or neuronal loss, and the onset of cognitive decline in $\mathrm{AD}$ [3-9]. In contrast, soluble oligomeric $A \beta$ assemblies $(\mathrm{o} A \beta$, also called $A \beta$-derived diffusible ligands), which range in size from tetramers to dodecamers and can accumulate intracellularly, show correlation with synaptic loss and synaptic impairment in many in vitro studies. Soluble oA $\beta$ binds preferentially to synapses [10], and addition of oA $\beta$ to mouse hippocampal slices results in inhibition of long-term potentiation [11]. This correlation has also been observed in vivo; the injection of $\mathrm{oA} \beta$ directly into the hippocampus of rats resulted in deficits in learning and memory $[2,12,13]$. While these data suggest that soluble oA $\beta$ represents the neurotoxic species in $\mathrm{AD}$ over insoluble fibrillar forms, the relationships between $\mathrm{oA} \beta$, neurodegeneration, and cognitive decline remain poorly defined, with most studies having only examined the toxicity of $\mathrm{OA} \beta$ in vitro or in vivo in mouse models that possess soluble oA $\beta$ as well insoluble $f A \beta$, and $A \beta$ plaques (see $[13,14]$ for review). Data generated from these mouse models produced results that can be difficult to interpret due to the presence of multiple $A \beta$ conformations.

Mutations in amyloid precursor protein $(A P P)$ are observed in patients with familial early-onset $\mathrm{AD}$ or dementia caused by cerebral amyloid angiopathy. Of the APP mutations causing $\mathrm{AD}$ or cerebral amyloid angiopathy, four occur at the E693 position of the protein, the Dutch (E693Q) [15], Arctic (E693G) [16] and Italian (E693K) [17] mutations and a deletion (E693A) [18]. In contrast to the pathological amyloid deposition observed in $\mathrm{AD}$, patients who carry the APP E693G (Arctic) or E693 $\triangle$ variants show little or no fibrillar $A \beta$ as detected by amyloid imaging $[18,19]$. Current imaging technologies cannot detect soluble oA $\beta$, which may be present in the brain, affect synaptic function and lead to the cognitive deficits observed in these patients. The present investigation sought to examine the effects of soluble oA $\beta$ on neuronal and synaptic structure in the APP E693Q ("Dutch"; DU) mouse model of $\mathrm{AD}$ that displays intraneuronal accumulation of soluble oA $\beta$ with no detectable plaques. This mouse model expresses the E693Q mutation of the APP [20]. Missense mutations in APP located near the middle of the $A \beta$ domain influence the propensity of $A \beta$ to form oligomeric assemblies by disrupting the salt bridges on the protein that typically stabilize parallel $\beta$-pleated sheets and favor fibril and plaque formation, thereby promoting the formation and intraneuronal accumulation of oA $\beta$ [21]. Severe meningocortical vascular deposition of $A \beta$ in patients with hereditary cerebral hemorrhage with amyloidosis caused by the DU mutation has also been described. Interestingly, these patients consistently develop cerebral hemorrhages but rarely display significant parenchymal amyloid plaque accumulation [22,23]. This was initially proposed to be related to the ratio of $A \beta 42 / 40$, with $A \beta 40$ being the dominant species, however subsequent studies revealed A 342 also plays a role in vascular amyloid formation [22,23]. Recent work by Gandy and colleagues indicates that the level of soluble oA $\beta$ in the DU mouse model correlates with diminished performance in the water maze compared to non-transgenic wild type (WT) littermates at 12 months [20], indicating that DU mice, which do not demonstrate extracellular deposits, exhibit perturbed hippocampus-associated spatial learning and memory.

Our goal was to complement these behavioral findings by performing quantitative analyses of neuronal pathology, including dendrite morphology, as well as spine and synapse numbers in individual hippocampal CA1 neurons. These morphological features of the neuron are the site of critical memory forming processes [24-26]. Twelve monthold DU mice were assessed, along with non-transgenic WT littermates, for comparison of dendritic length and complexity, and quantification of dendritic spines and synapse densities. Structural components of synapses such as postsynaptic density (PSD) length and synapse head diameter of individual pyramidal CA1 neurons were also examined. We show that DU mice displayed morphological changes in CA1 neurons compared to WT mice, including significantly reduced dendritic arborization of apical dendrites along with decreases in PSD length of synapses on mushroom spines. These structural alterations to neurons in DU mice support the concepts that the soluble oA $\beta$ species have adverse effects at the synaptic level along with major structural disturbances, and that changes at the synapse correlate with early cognitive impairments in $\mathrm{AD}$.

\section{Results}

\section{Confirmation of $O A \beta$ in the DU mouse model}

Before beginning the neuroanatomical comparisons in DU and WT mice, it was first necessary to confirm 
transgene expression and the presence of oA $\beta$ in the DU mice. Using the $6 \mathrm{E} 10$ anti-A $\beta$ antibody we found that DU mice expressed amyloid and exhibited accumulation of intracellular $\mathrm{A} \beta$ (Figure 1A, D) and not extracellular plaques as in the TgCRND8 mice (Figure 1B, E), confirming results from previous studies [20,27]. No amyloid pathology was observed in WT mice (Figure 1C, F).

\section{Effects of $O A \beta$ on dendritic length and arborization}

We assessed whether CA1 neurons from DU mice would display differences in dendritic length and complexity compared to neurons from WT mice, and predicted that apical and basal dendrites from DU mice would be atrophic, and display perturbed arborization and complexity compared to WT mice. Representative examples of CA1 dendritic arbor reconstructions and dendrograms of WT and DU neurons are depicted in Figure $2 \mathrm{~A}$ and $\mathrm{B}$. Dendritic measurements revealed a significant decrease in the length of apical dendrites (Figure $2 \mathrm{C}, t_{(15)}=2.828 ; \mathrm{p}=0.013$ ) but not in basal dendrites (Figure 2D, $t_{(15)}=0.857 ; \mathrm{p}=0.405$ ) in DU mice compared to WT (Table 1). To characterize the branching characteristics of individual neurons and their radial complexity, we performed Sholl analysis on apical and basal dendrites of DU and WT CA1 neurons. Sholl analysis of apical dendritic length and intersections revealed significant effect of genotype on the dendritic length (Figure 2E, $\mathrm{F}_{(1,168)}=6.31 \mathrm{p}=0.013$ ) and intersections (Figure 2G, $\mathrm{F}_{(1,168)}=0.82, p=0.01$ ) in DU dendrites compared to WT mice. These differences were most pronounced at a distance of $120 \mu \mathrm{m}$ and $150 \mu \mathrm{m}$ away from the soma, respectively. When basal dendrites were analyzed there were no significant differences observed for both basal dendritic length (Figure $\left.2 \mathrm{~F}, \mathrm{~F}_{(1,}, 112\right)=0.01$ $\mathrm{p}=0.923$ ) and basal intersections (Figure $2 \mathrm{H}, \mathrm{F}_{(1,112)}=$ $6.31 \mathrm{p}=0.999)$ between DU and WT mice. Together these data suggest that soluble oA $\beta$ primarily affects the apical dendritic arbors, with no effect on basal dendrites of CA1 pyramidal neurons when it accumulates in situ. It remains to be assessed whether these effects are the result of decreased input to the CA1 from other affected hippocampal areas or a local effect in the CA1 region.

\section{Effects of $o A \beta$ on spine density and spine subtype}

With the dendritic atrophy observed in apical dendrites in response to the accumulation of soluble oA $\beta$, it is also possible that there may be alterations in dendritic spine density or the proportion of spine subtypes. We therefore analyzed WT and DU neurons for changes in the density of dendritic spines. We compared overall spine density of DU and WT mice, and also examined possible changes in thin, stubby, and mushroom spines, separately (Figure 3 ; Table 1 ). We observed no significant differences in the density of total, apical or basal stubby and thin spines in DU mice compared to WT mice (Figure $3 \mathrm{C}-\mathrm{H}$ ). When we analyzed total mushroom spine density we found a slight decrease between Dutch mice and controls $\left(t_{(8)}=1.967 ; \mathrm{p}=0.085\right)$. When we separated spines into apical and basal dendrites we observed a decrease in apical but not basal mushroom spine density $\left(\mathrm{t}_{(8)}=2.193 ; \mathrm{p}=0.06 ;\right.$ and $t_{(8)}=0.032 ; \mathrm{p}=0.975$ respectively); however, as above, this did not reach significance.
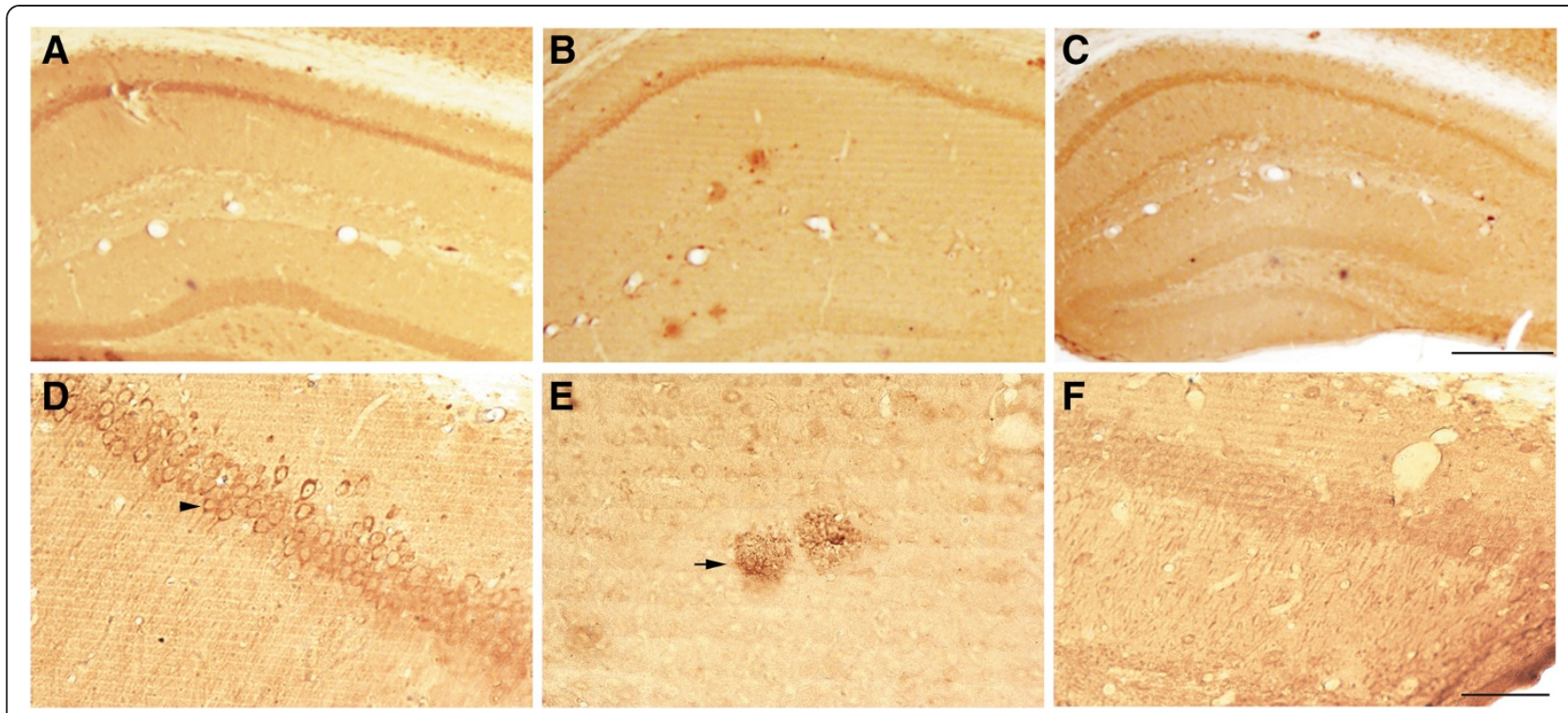

Figure 1 APP/A $\beta$ pathology in the hippocampus of Dutch mutant APP and TgCRND8 mutant APP transgenic mice. A $\beta$ and APP species were visualized using the $6 \mathrm{E} 10$ antibody. Intracellular APP/A -like immunoreactivity (arrowhead) is evident in DU mice (A and D) while extracellular amyloid plaques (black arrow) are evident in TgCRND8 APP transgenic mice (B and E). No APP/AB immunoreactivity is seen in WT mice (C and F). A-C scale $=500 \mu \mathrm{m} ; \mathbf{D}-\mathbf{F}$ scale $=100 \mu \mathrm{m}$. 

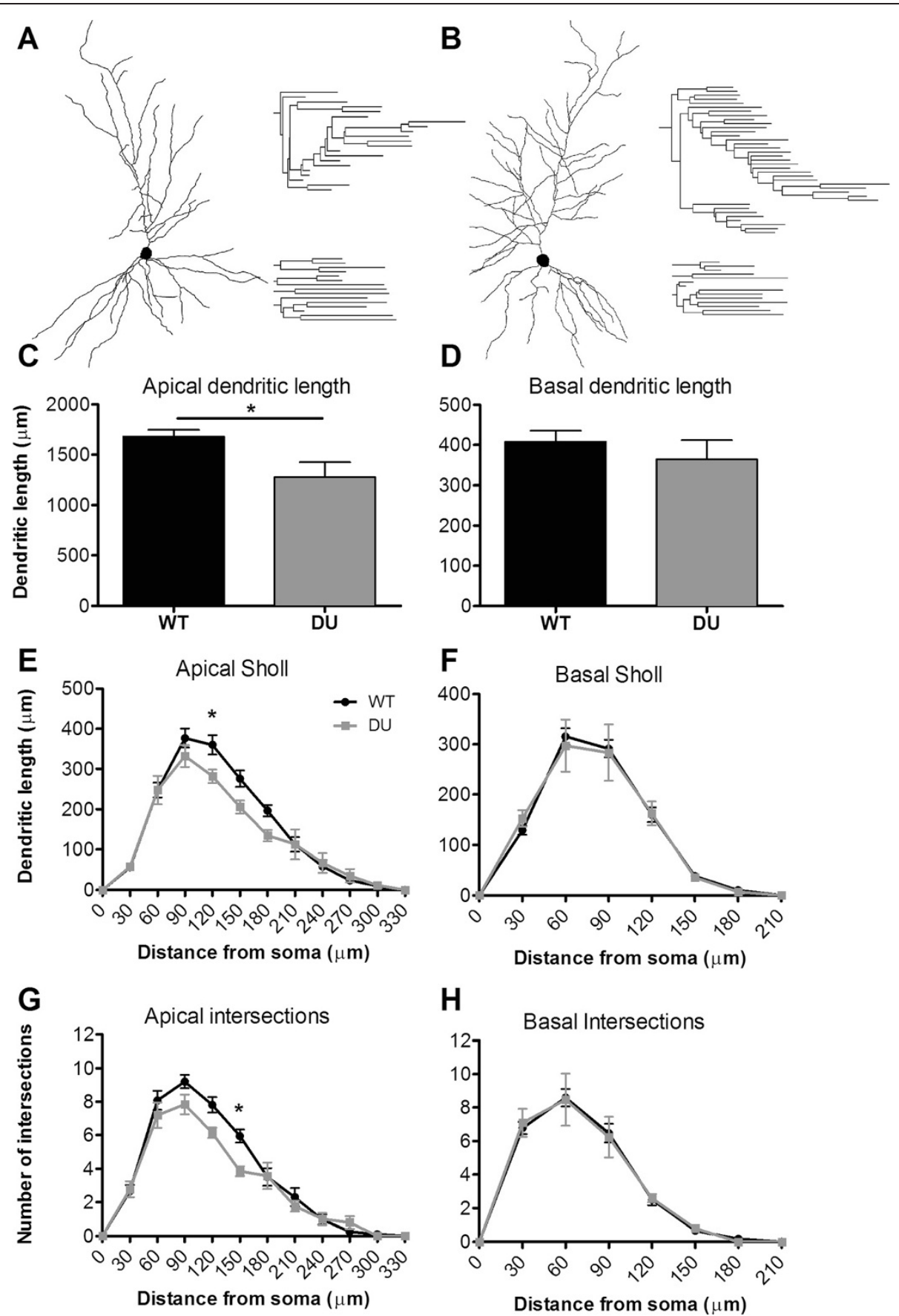

Figure 2 Alterations in neuronal morphology with amyloid pathology. Representative neuronal traces of WT and DU neurons and their apical and basal dendrograms are represented in A and B, respectively. Significant differences were observed in apical but not basal length (C and D). Sholl analysis revealed a significant decrease in apical dendritic length (E) and intersections at $120 \mu \mathrm{m}$ and $150 \mu \mathrm{m}$ away from the soma, respectively, in DU neurons compared to WT $(\mathbf{G})$, but this finding was not repeated for basal dendrites $(\mathbf{F}, \mathbf{H})$. Data represent group mean \pm SEM $(n=11$ WT and $5 \mathrm{DU}) .{ }^{*} p<0.05$.

When the apical spine densities for each subtype were separated into proximal (50-100 $\mu \mathrm{m}$ from the cell soma) and distal ( $>100 \mu \mathrm{m}$ from the cell soma), no differences were observed, and these data were therefore pooled.

\section{Effects of $o A \beta$ on synapses}

Next we asked whether oA $\beta$ affects the density of perforated and non-perforated synapses on spines from both the stratum radiatum (SR) and the stratum lacunosum- 
Table 1 Apical dendritic, spine and synapse morphology from CA1 pyramidal neurons of DU and WT mice

\begin{tabular}{lll}
\hline \multicolumn{2}{l}{ Genotype } & \\
& DU & WT \\
\hline Apical dendritic length $(\boldsymbol{\mu m})$ & $1277.65 \pm 147.79$ & $1507.37 \pm 154.86$ \\
Spine density (Spines/ $\mu \mathrm{m})$ & & \\
Total & $2.676 \pm 0.164$ & $2.674 \pm 0.118$ \\
Thin & $1.585 \pm 0.307$ & $1.548 \pm 0.133$ \\
Stubby & $1.114 \pm 0.177$ & $1.007 \pm 0.097$ \\
Mushroom & $0.199 \pm 0.014$ & $0.237 \pm 0.012$ \\
Synapse density $\left(\boldsymbol{\mu m ^ { 3 }}\right)$ & & \\
Total & $2.897 \pm 0.304$ & $2.830 \pm 0.250$ \\
Perforated & $0.097 \pm 0.013$ & $0.123 \pm 0.023$ \\
Non-perforated & $2.800 \pm 0.297$ & $2.829 \pm 0.250$ \\
Synapse morphology $(\boldsymbol{\mu m})$ & & \\
PSD length & $0.300 \pm 0.007$ & $0.327 \pm 0.006$ \\
Head Diameter & $0.529 \pm 0.014$ & $0.551 \pm 0.006$ \\
\hline
\end{tabular}

moleculare (SLM) dendritic domains. Approximately 1500 synapses were reconstructed (130/animal on average) across serial EM sections using the disector method. Analysis of the density of non-perforated and perforated synapses from SR and SLM revealed no significant difference between WT and DU mice (Figure 4A, B; Table 1). Structural alterations to individual synapses were examined by measuring the maximum head diameter and PSD lengths of synapses across DU and WT animals. When average maximum head diameter of synapses was analyzed, no major differences in mean values was observed (WT $=0.392 \mu \mathrm{m}, \mathrm{DU}=0.393 \mu \mathrm{m}$, Figure $4 \mathrm{C}$ ), and the range of values did not change significantly for each genotype $(\mathrm{WT}=0.143-0.942 \mu \mathrm{m}, \mathrm{DU}=0.182-0.999 \mu \mathrm{m})$. Similarly, we found that the means for PSD lengths for each genotype were close to identical (WT $=0.243 \mu \mathrm{m}$, $\mathrm{DU}=0.238 \mu \mathrm{m}$, Figure 4D). When we determined the range of PSD lengths for DU and WT mice, these were also similar $(\mathrm{WT}=0.094-0.609 \mu \mathrm{m}, \mathrm{DU}=0.112-$ $0.453 \mu \mathrm{m})$. Cumulative frequency curves of both synapse head diameter and PSD lengths to compare their

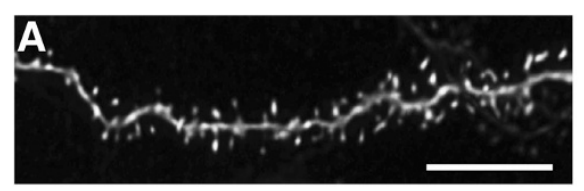

C Total stubby

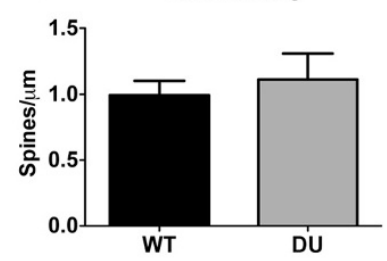

$\mathbf{F}$

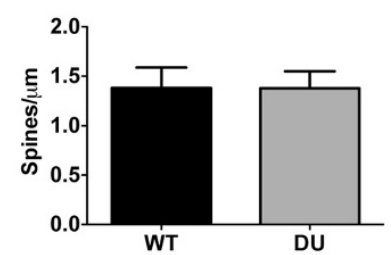

I

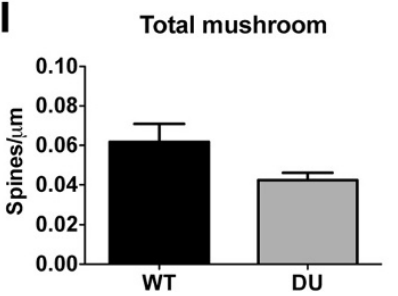

D Apical stubby

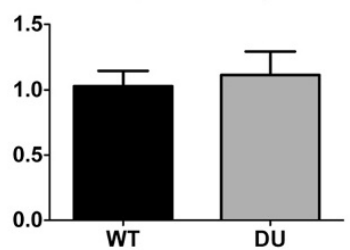

G
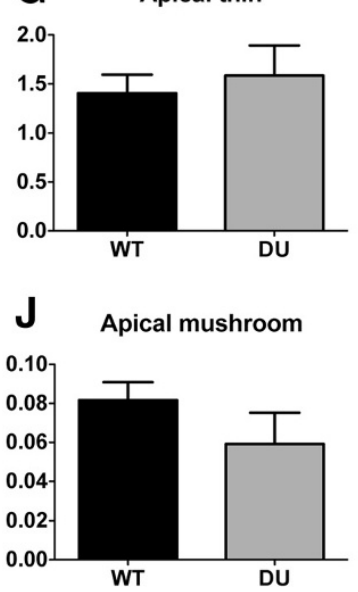

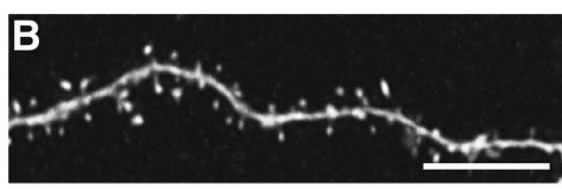

E
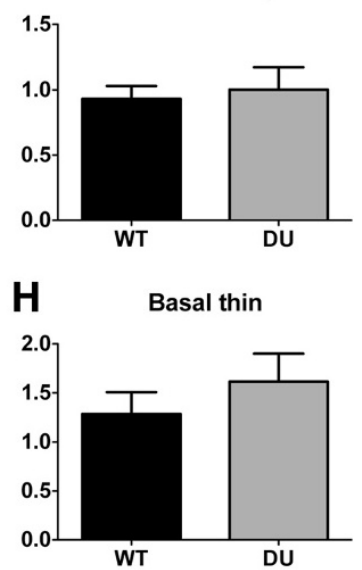

K Basal mushroom

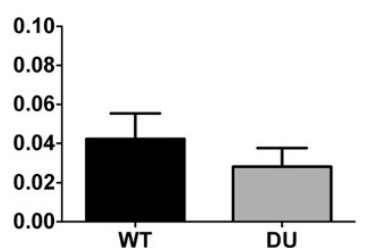

Figure 3 No significant changes in dendritic spine density in DU mice compared to controls. Representative images of deconvolved WT and DU dendrites in 3D with spine visualization (A \& B). When spine density was analyzed, no changes were observed for total, thin, and stubby spines on apical and basal dendrites in DU and WT neurons (C-H). Analysis of mushroom spines revealed a decrease in density however, this did not reach significance (I-K). Data represent group mean \pm SEM. Scale bars $=5 \mu \mathrm{m}$. 

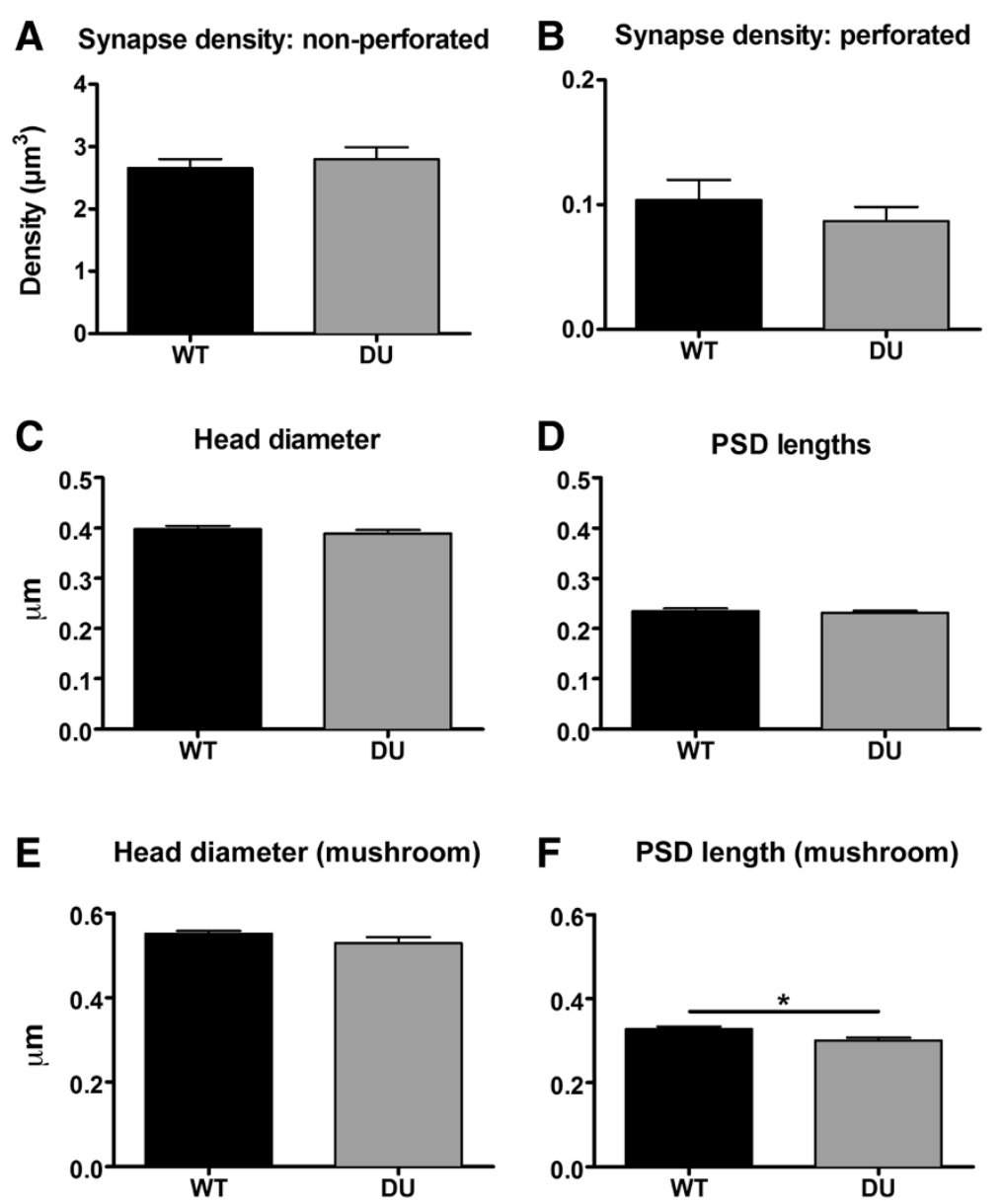

Figure 4 PSD length is significantly decreased in mushroom spines in DU mice. The synapse density of perforated and non-perforated synapses in WT and DU mice remained unchanged (A \& B), and the maximum head diameter of synapses and PSD lengths was also unchanged across genotypes in the SR and SLM dendritic region ( $C \& \mathbf{D}, n=10 /$ genotype). When synapses only on mushroom spines in the SR were analyzed, synapse head diameter remained constant, whereas a significant decrease in PSD length of DU synapses was observed $\left(\mathbf{E} \& \mathbf{F},{ }^{*} p<0.05\right.$, two-tailed $t$-test, $n=5 /$ genotype). Data represent group mean \pm SEM.

distribution in DU and WT mice failed to reveal any significant differences (Kolmogorov-Smirnov test, see Additional file 1: Figure S1). When data were separated according to either SR or SLM, we also saw no changes to these synaptic parameters (data not shown).

We reasoned that there might be changes to the synaptic characteristics on specific spine subtypes. We chose to focus our investigation here on the mushroom spine subtype since this spine subtype is implicated in the formation and maintenance of memory $[28,29]$. Although we did not observe any changes in maximum head diameter and PSD length in Figure 4C \& D, any changes to synapses on mushroom spines may have been masked by the pooling of our synapse measurements from all spine subtypes. Therefore, we analyzed the maximum head diameter and PSD length of mushroom spines. When synapses on mushroom spines were analyzed separately in this way, we observed a significant decrease in PSD lengths for synapses on mushroom spines in DU mice compared to WT with no change in maximum head diameter (Figure 4F, $t_{(8)}=3.025 ; \mathrm{p}=0.016$ ).

\section{Discussion}

$A \beta$ and its proposed neurotoxicity has been the focus of $\mathrm{AD}$ research since it was identified in the brains of $\mathrm{AD}$ patients three decades ago [30,31]. The discovery that $\mathrm{A} \beta$ has a variety of conformations, and the lack of correlation between cognitive decline and plaque accumulation, has prompted researchers to reassess the 'amyloid cascade hypothesis' that dominated early $\mathrm{AD}$ research [32]. Recent advances in early AD diagnosis have enabled amyloid PET imaging, using ligands such as florbetapir [33] and Pittsburgh Compound-B [34] to detect $A \beta$ deposits. However, these studies have also validated that hippocampal neurodegeneration is unrelated to rate of $A \beta$ deposition [35]. The strong correlation between soluble conformations of $A \beta$ and cognitive impairments, along with synaptic dysfunction and loss has shifted the 
focus of amyloid research towards soluble, oligomeric $\mathrm{A} \beta$ conformations as the 'toxic species' [32]. Indeed, monomeric and oligomeric forms of $A \beta$ have been reported to accumulate in synapses of AD brains as compared to controls [36]. However, new tools and models to discriminate between different $A \beta$ aggregation states have not been available until recently [37], and despite reports of altered dendritic spine and synaptic morphology in a variety of $\mathrm{AD}$ experimental models, there is limited knowledge about how soluble oA $\beta$ may affect these structural parameters in a model that does not also accumulate amyloid plaques.

In the current study, we have utilized a mouse model of AD that expresses the Dutch variant of APP. In silico modeling of $A \beta$ fibrillization [38], cell-free aggregation experiments [39] and in vitro experiments [40,41] showed that the Dutch mutation increased fibrillization of $A \beta$. Indeed, the Dutch mutation increases deposition of $A \beta$ in vascular tissue but has the opposite effect in parenchyma of the transgenic mice, as is seen in patients carrying this mutation [42]. In contrast to the mice used in the Herzig study, which expressed both normal and Dutch APP, the DU mice we used in the current study expressed Dutch APP and only produces soluble oA $\beta$, with no detectable plaques up to 30 months of age [20] (Figure 1). The DU mice display cognitive deficits in spatial memory tasks at 12 months of age, indicating that soluble oA $\beta$ may be inducing these effects in the absence of $f A \beta$. Here we demonstrate that CA1 pyramidal neurons exhibit changes to neuronal morphology and total spine and synapse density. We selected the CA1 region for analysis since it is implicated in long-term contextual memory retrieval $[43,44]$, which is affected in AD [45]. Neocortical pyramidal neurons possess extensive apical and basal dendritic trees, which integrate information from thousands of excitatory and inhibitory synaptic inputs [6]. The morphological features of a dendrite, such as its length and complexity, can influence how a neuron processes and transmits information [46-49], and many in vivo studies do report neuronal atrophy with proximity to $f A \beta$ in the brain and subsequent functional deficits (see [6] for review). The effects of oA $\beta$ are less well characterized, although oA $\beta$ has been implicated in alterations to overall dendritic spine number and type in $\mathrm{AD}$. Most studies on spines in AD models report either a spine loss, or a shift in the proportion of thin, stubby, or mushroom spine types, which are proposed to have unique roles, complementing their distinctive morphology [3,50-52]. For example, thin spines contain a predominantly greater number of the $N$-methyl-D-aspartate glutamate receptors (NMDARs) compared to large, mushroom spines that contain more 2-amino-3-(3-hydroxy-5-methylisoxazol-4-yl)propanoic acid receptors (AMPARs), making synapses on mushroom spines functionally stronger [28].
This suggests that the more plastic, thin spines are linked to learning, whereas mushroom spines may represent more stable, 'memory' spines [28,29]. A growing number of reports support the notion that spines and synapses are the initial site of A $\beta$-mediated neurotoxicity [24-26,53], and it is probable that more dramatic oA $\beta$-driven disturbances in DU mice are occurring at the synaptic receptor level, which we did not examine here. Excitatory glutamatergic NMDARs, AMPARs and other critical synaptic proteins may be affected in DU mice, with reduced expression and altered distribution of NMDA and AMPA receptors. Other in vitro and ex vivo experimental models have reported direct binding of soluble $A \beta$ to synaptic proteins at the PSD [53-55] and these observations are supported by the decrease in PSD length in DU mice we observed in this study.

The significant decrease we observed in PSD length of synapses only on apical mushroom spines may reflect disturbances in synaptic function and memory impairment in the presence of oA $\beta$. A similar finding was reported by Nicholson et al. (2004) in their study of aged, learningimpaired Long Evans rats. These authors reported a significant $(\sim 30 \%)$ decrease in PSD length of CA1 SR synapses in the impaired group compared to control rats [56], and noted that the decrease was only apparent in perforated synapses, which are defined by a discontinuity of the electron dense plate on the post-synaptic membrane into two or more parts [57,58]. Although the decrease in PSD length we observed in DU mice for synapses in the same brain region were not as dramatic, our data is supported by this study as perforated synapses typically occur only on mushroom spines implicated in memory formation $[28,29]$. This is because the shape of the PSD can increase in complexity with increasing spine size [57]. Furthermore, perforated synapses have been proposed to enhance synaptic efficacy by increasing the surface area for receptor activation $[56,59,60]$. A decrease in PSD length would therefore reduce glutamate receptor content and impair synaptic efficacy, leading to functional disturbances [60]. Within the context of the current study, a decrease in PSD length suggests that hippocampal perforated synapses are selectively affected by soluble oA $\beta$, correlating with the observed cognitive deficits in 12 month-old DU mice. Alternatively, it is possible that although we did not observe any changes in perforated and non-perforated synapses or total synapse number, the DU mice may have an increased proportion of AMPAtype 'silent' synapses. These express NMDARs, but lack functional AMPARs [61], and do not generate a synaptic response following glutamate release at normal resting membrane potentials [62]. In electron micrographs, they are structurally identical to functional synapses, and can only be distinguished by a lack of AMPA immunoreactivity [62-67]. When a study by Geinisman et al. (2004) 
found no changes in perforated and non-perforated synapses, and total synapse numbers in the SR dendritic domain of CA1 neurons of cognitively impaired, aged rats compared to control rats, they argued that this may be due to an increased proportion of silent synapses [62]. Because silent synapses may become functional during postnatal development and the induction of hippocampal long-term potentiation, it is also possible that functional synapses in CA1 pyramidal neurons become increasingly silent with age [62], leading to a loss of synaptic activity without diminished synapse numbers. Further support for an oA $\beta$-driven increase in silent synapses comes from other work using both the transgenic mice carrying the Swedish APP mutation and the external application of $\mathrm{oA} \beta$ to rat cortical neurons, which found that $\mathrm{oA} \beta$ altered the distribution and reduced the expression of $\mathrm{Ca}^{2+} /$ calmodulin-dependent protein kinase II (CaMKII) [68]. CaMKII is a critical scaffolding protein highly enriched at PSDs that is required for transporting AMPARs to the synapse, and switching synapses from silent to functional through AMPA delivery [69,70]. A reduction in the expression of CaMKII following oA $\beta$ exposure therefore provides a mechanism for increased silent synapses to occur. Interestingly, no changes in dendritic spine density were also found by another group using oA $\beta$ externally applied to rat cortical cultures compared to controls [68]. Further analysis of the DU mice using immunogold electron microscopy (EM) will help to clarify if soluble oA $\beta$ accumulated in situ influences the proportion of silent synapses or dramatically alters the expression and distribution of synaptic receptors in the CA1. Additional behavioral and immunogold EM analyses in older DU mice (18 and 24 month-old) will also reveal whether their cognitive deficit and neuropathology worsens with age.

\section{Conclusions}

In the present study, we report that accumulation of soluble oA $\beta$ only in DU mice leads to discernible morphological changes to neurons, with an increase in dendritic atrophy accompanied by a decrease in PSD length that may be responsible for the cognitive impairment seen in these mice. Many in vitro studies on the putative neurotoxicity of oA $\beta$ to dendrites, spines, and synapses that do report changes to neuronal morphology have used synthetic oA $\beta$ preparations that may not accurately match the toxicity profile of naturally occurring oA $\beta$ species occurring in vivo [71]. In addition, mouse models of AD up to this point have expressed both soluble oA $\beta$ and insoluble fibrillar species, hindering clarification of the 'conformation-specific' neurotoxic effects of $A \beta$. Interestingly, in these models of $\mathrm{AD}$, loss of dendritic spines or synaptic proteins has been observed prior to $A \beta$ plaque deposition or in brain areas without $\mathrm{A} \beta$ plaques (reviewed in [72]). Methodological inconsistencies and the lack of adequate mouse models to assess only oA $\beta$ in situ prior to this point, means that care should be taken in the interpretation of individual AD studies. Importantly, this also highlights the need for consistent methodological practices across $\mathrm{AD}$ research for improving and accelerating our understanding of the disease. We propose that the DU mouse model of AD represents a useful tool for the assessment of oA $\beta$-mediated synaptic changes, based on our findings of detectable synaptic changes parallel to the onset of cognitive deficits in this model. Future studies using transgenic models expressing the Dutch, Arctic or E693 $\Delta$ variants of APP and aimed at the development of imaging techniques to detect $\mathrm{o} A \beta$, in the absence of $\mathrm{A} \beta$ deposits would enable correlation of these synaptic changes with a potential clinical diagnostic tool.

\section{Methods}

\section{Experimental animals}

Male and female 12-month old mice were used in the study. All animals were group housed in micro-isolator cages under a 12-hour light/dark cycle and given ad libitum access to food and water. The DU mice used in the study contain the human APP gene harboring the Dutch mutation (APP E693Q) under control of the Thy1 promoter [20]. These mice exhibit intraneuronal accumulation of soluble oA $\beta$ with no detectable plaques, in addition to the appearance of amyloid-laden cerebral vessels and occasional extravasation of blood from vessels without gross hemorrhage [20]. TgCRND8 mice express double mutations within the human APP 695 isoform (Swedish K670M/N671L and Indiana V717F mutations) under control of the hamster prion promoter. These mice overexpress human $A \beta$ by $3-4$ months, have a high $A \beta_{42} / A \beta_{40}$ ratio and exhibit plaque deposition, activated microglia, neuronal loss and cognitive deficits as early as 3 months of age [73-75]. All animal procedures were conducted in accordance with the National Institute of Health Guidelines for the Care and Use of Experimental Animals and were approved by the Institutional Animal Care and Use Committee at the Icahn School of Medicine at Mount Sinai. For cell loading and EM experiments, we included $n=5$ mice/group and imaged a minimum of 5 neurons/mouse with DU mice being compared to WT mice.

\section{Mouse perfusions}

Mice were anesthetized and perfused with $1 \%$ paraformaldehyde (PFA) followed by $4 \%$ PFA with $0.125 \%$ glutaraldehyde as described previously [75,76]. The brains were removed, hemisected, postfixed overnight, and sectioned on a Vibratome (Leica VT1000S) into $200 \mu$ m-thick sections for cell loading experiments and $250 \mu \mathrm{m}$ for EM. All sections were stored at $4^{\circ} \mathrm{C}$ in phosphate buffered saline (PBS) until ready for use. 


\section{Immunohistochemistry}

Free-floating hippocampal brain slices from DU and WT mice were processed for immunohistochemistry for $A \beta$ using the $6 \mathrm{E} 10$ anti-A $\beta$ antibody (Covance) as previously described [27,77]. The mAb $6 \mathrm{E} 10$ is specific for amino acids $1-16$ of human $A \beta$, with the epitope lying within amino acids $3-8$ of $A \beta$ (EFRHDS). Brain slices from TgCRND8 mice that accumulate dense cored $A \beta$ plaques [73], were stained in parallel as a positive control. Images were acquired on a Zeiss Axiophot 2 microscope equipped with a motorized stage and video camera system using 2.5x/0.075 N.A., Plan-Neofluar and a 40x/1.3 N.A., Plan-Neofluar oil immersion objectives.

\section{Intracellular dye injections}

For intracellular injections, sections were incubated in 4,6-diamidino-2-phenylindole (DAPI; Vector Labs) for 5 min to reveal the cytoarchitectural features of the pyramidal layer of CA1 of the hippocampus. The sections were then mounted on nitrocellulose paper and immersed in ice-cold 0.1 M PBS. Pyramidal neurons in the CA1 were subjected to an intracellular iontophoretic injection of $5 \%$ Lucifer Yellow (Molecular Probes) in distilled water under a direct current of 3-8 nA until dye had completely filled distal processes $[75,76,78]$. Five to 10 neurons were injected per slice and placed far enough apart to avoid overlapping of their dendritic trees. Brain sections were then mounted on gelatin-coated glass slides and cover slipped in Fluoromount G slide-mounting media (Cell Lab Beckman Coulter).

\section{Neuronal and dendritic reconstruction}

To be included in the analysis, a loaded neuron had to satisfy the following criteria: (1) reside within the pyramidal layer of the CA1 as defined by cytoarchitectural characteristics; (2) demonstrate complete filling of dendritic tree, as evidenced by well-defined endings; and (3) demonstrate intact tertiary branches, with the exception of branches that extended beyond $50 \mu \mathrm{m}$ in radial distance from the cell soma $[75,76,78]$. Neurons meeting these criteria were reconstructed in 3-dimensions (3D) with a $40 \times / 1.4$ N.A., Plan-Apochromat oil immersion objective on a Zeiss Axiophot 2 microscope equipped with a motorized stage, video camera system, and Neurolucida morphometry software (MBF Bioscience). Using NeuroExplorer software (MBF Bioscience) total dendritic length, number of intersections, and the amount of dendritic material per radial distance from the soma, in 30- $\mu \mathrm{m}$ increments [79] were analyzed in order to assess morphological cellular diversity and potential differences between the animal groups.

\section{Confocal microscopy and spine acquisition}

Using an approach that precludes sampling bias of spines, CA1 dendritic segments were selected with a systematic- random method [80,81]. Dendritic segments, 20-25 $\mu \mathrm{m}$ in length, were imaged on a Zeiss CLSM 510 microscope (Zeiss) using a $100 \times / 1.4$ N.A. Plan-Apochromat objective with a digital zoom of 3.5 and an $\mathrm{Ar} / \mathrm{Kr}$ laser at an excitation wavelength of $488 \mathrm{~nm}$. All confocal stacks were acquired at $512 \times 512$ pixel resolution with a z-step of $0.1 \mu \mathrm{m}$, a pinhole setting of 1 Airy unit and optimal settings for gain and offset. All confocal stacks included approximately $1 \mu \mathrm{m}$ above and below the identified dendritic segment. On average 6 z-stacks were imaged per neuron, 3 for the apical dendritic tree and 3 for the basal dendritic trees. To be optically imaged, a dendritic segment had to satisfy the following criteria: (1) the entire segment had to fall within a depth of $50 \mu \mathrm{m}$; (2) dendritic segments had to be either parallel or at acute angles to the coronal surface of the section; and (3) segments could not overlap other segments that would obscure visualization of spines [80,81]. Confocal stacks were then deconvolved using an iterative blind deconvolution algorithm (AutoDeblur version 8.0.2; MediaCybernetics).

\section{Spine analysis}

After deconvolution, confocal stacks were analyzed with NeuronStudio [82-84] (http://research.mssm.edu/cnic/) to examine global and local morphometric characteristics of dendrites and spines such as dendritic spine densities and dendritic spine shape. This software allows for automated digitization and reconstructions of neuronal morphology in 3D from multiple confocal stacks on a spatial scale and averts the subjective errors encountered during manual tracing using a Rayburst-based spine analysis [82-84]. Spines were classified as 'stubby' if they had a head to neck diameter ratio less than 1.1, 'thin' spines were identified by a head to neck diameter ratio greater than 1.1 and a maximum head diameter less than $0.4 \mu \mathrm{m}$. 'Mushroom' spines were identified by a head to neck diameter ratio greater than 1.1 and a maximum head diameter greater than $0.4 \mu \mathrm{m}$ [85]. Five animals per genotype, five neurons per mouse and three apical and three basal dendritic segments per neuron were analyzed with each segment manually inspected and appropriate corrections made using the NeuronStudio interface.

\section{Electron microscopy}

Coronal sections $(250 \mu$ m-thick $)$ encompassing the CA1 region of the hippocampus were prepared for EM as reported previously [86]. Briefly, slices were cryoprotected in graded phosphate buffer/glycerol washes at $4^{\circ} \mathrm{C}$, and manually microdissected to obtain blocks containing the CA1 region. The blocks were rapidly freeze-plunged into liquid propane cooled by liquid nitrogen $\left(-190^{\circ} \mathrm{C}\right)$ in a Universal cryofixation System KF80 (Reichert-Jung) and subsequently immersed in $1.5 \%$ uranyl acetate dissolved in anhydrous methanol at $-90^{\circ} \mathrm{C}$ for 24 hours in a 
cryosubstitution unit (Leica). Block temperatures were raised from -90 to $-45^{\circ} \mathrm{C}$ in steps of $4^{\circ} \mathrm{C}$ /hour, washed with anhydrous methanol, and infiltrated with Lowicryl resin (Electron Microscopy Sciences) at $-45^{\circ} \mathrm{C}$. The resin was polymerized by exposure to ultraviolet light $(360 \mathrm{~nm})$ for 48 hours at $-45^{\circ} \mathrm{C}$ followed by 24 hours at $0^{\circ} \mathrm{C}$. Block faces were trimmed and ultrathin sections $(90 \mathrm{~nm})$ were cut with a diamond knife (Diatome) on an ultramicrotome (Reichert-Jung) and serial sections of at least 5 sections were collected on formvar/carbon-coated nickel slot grids (Electron Microscopy Sciences).

\section{Quantitative analyses of synapse density, PSD length, and spine head diameter}

For synapse quantification, serial section micrographs were imaged at 15,000x on a Hitachi $\mathrm{H}-7000$ transmission electron microscope using an AMT Advantage CCD camera (Advanced Microscopy Techniques). Twelve sets of serial images across the same set of 5 consecutive ultrathin sections were taken from the SR and SLM of the hippocampus CA1 field and imported into Adobe Photoshop (version CS5, Adobe Systems). To obtain a stereologically unbiased population of synapses for quantitative morphologic analysis, we used a disector approach on ultrathin sections as in previous reports $[87,88]$. Briefly, all axospinous synapses were identified within the first and last 2 images of each 5 -section serial set, and counted if they were contained in the reference image but not in the corresponding look-up image. To increase sampling efficiency, the reference image and look-up image were then reversed; thus each animal included in the current study contributed synapse density data from a total of 30 dissector pairs. The total volume examined was $11.317 \mu^{3}$, and the height of the disector was $180 \mathrm{~nm}$. Axospinous synapse density (per $\mu \mathrm{m}^{3}$ ) was calculated as the total number of counted synapses from both images divided by the total volume of the disector. The criteria for inclusion as an axospinous synapse included the presence of synaptic vesicles in the presynaptic terminal and a distinct asymmetric PSD separated by a clear synaptic cleft (Figure 5A \& B). The synapse density was calculated as the total number of counted synapses divided by the total volume of the disectors used. For a synapse to be scored as perforated it had to display two or more separate PSD plates (Figure 5C). Spine head diameter and PSD length were of interest because they are indicative of spine plasticity and glutamate receptor representation [88]. For instance, small, thin spines are thought to be more motile and plastic than larger mushroom spines [88-90]. PSD length measurements and maximum spine head diameter were determined using a method previously described [88]. Briefly, all axospinous synapses in the middle portion of three serial sections were identified. Then, for each synapse, the longest PSD length and spine head diameter in 3 serial sections was identified and measured (Figure 5D). If the synapse only spanned 2 out of the 3 serial sections, the longest PSD and head diameter from 2 sections was measured. For the smallest class of synapses that were only present in 1 serial section, measurements were taken in that section. According to Hara et al. (2011), while this method of measuring PSD lengths and head diameter results in a 5.5\% underestimation of true PSD length and head diameter, it applies across all animals and is not likely to bias systematically the outcome of group comparisons [88]. For perforated synapses, the lengths of all PSD segments were summed and the total length was used in the statistical analyses. Approximately 130 synapses were counted per animal.

\section{Statistics}

All statistical analyses were performed using GraphPad Prism 5 software (GraphPad Software Inc). For neuron morphology and spine and synapse data, values for single cells were averaged for each animal and then per genotype and analyzed with GraphPad Prism 5. For the mean apical and basal dendritic length, and all spine and

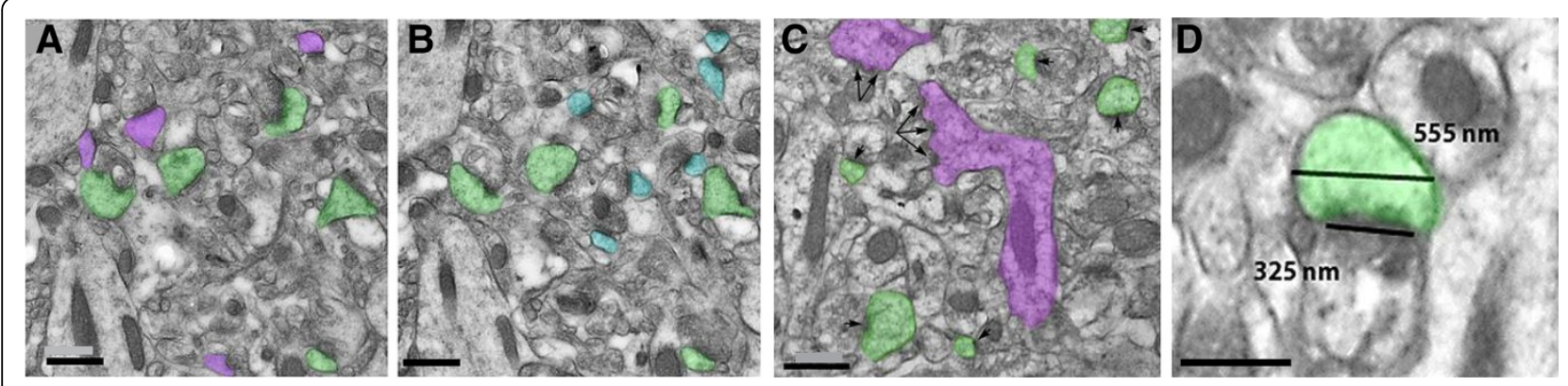

Figure 5 Identification of axospinous synapses using the disector method. Electron micrographs depicting synapses counted using the disector method (A \& B). Only asymmetric axospinous synapses that are present in the reference panel (purple or blue), but not in the look-up panel were counted. Synapses present in both panels (green) were not included in the analysis. Perforated synapses (C, purple) were classified by the presence of a discontinuity (or more than one) within the postsynaptic density (PSD) as shown by the vector arrows. Maximum head diameter of synapses and PSD length were measured as indicated in D (scale bars $=500 \mathrm{~nm}$ ). 
synapse data, a two-tailed Student's $t$-test was performed. Sholl analysis was performed on apical and basal dendrites for total dendritic length, number of intersections and amount of dendritic material. Both Sholl and intersection analyses were analyzed using two-way ANOVA followed by Bonferroni's post-hoc tests. To determine if the frequencies of different sized dendritic synapses differed between DU and WT mice, cumulative frequency curves of maximum spine head diameter and PSD length were examined using the KolmogorovSmirnov test. There were no statistical differences between male and female mice for these data, therefore sexes were grouped together. The statistical significance level for all data was set at an $\alpha$ level of 0.05 and all data were represented as mean \pm SEM.

\section{Additional file}

Additional file 1: Figure S1. Cumulative frequency curves of synapse head diameter and PSD length. Cumulative frequency curves of synapse head diameter (A) and PSD length (B) of synapses on CA1 hippocampal neurons in DU and WT mice. No shift in the distribution of head diameter or PSD length of CA1 synapses was observed in DU and WT mice.

\begin{abstract}
Abbreviations
Aß: Amyloid beta peptide; AMPAR: 2-amino-3-(3-hydroxy-5-methyl-isoxazol-4-yl) propanoic acid receptor; AD: Alzheimer's disease; APP: Amyloid precursor protein; CAMKII: $\mathrm{Ca}^{2+} /$ calmodulin dependent protein kinase II; DAPI: 4',6diamidino-2-phenylindole; DU: Dutch; EM: Electron microscopy; fA $\beta$ : Fibrillar A $\beta$; NMDAR: N-methyl-D-aspartate receptor; OA $\beta$ : Oligomeric A $\beta$; PBS: Phosphatebuffered saline; PFA: Paraformaldehyde; PSD: Postsynaptic density; SLM: Stratum lacunosum-moleculare; SR: Stratum radiatum; WT: Wild type.

\section{Competing interests}

The authors declare that they have no competing interests.

\section{Authors' contributions}

Study concept and design: KAP, DLD. Acquisition of data: KAP, AS, FY, HB, DLD. Analysis and interpretation of the data: KAP, DLD. Drafting of the manuscript: KAP, MV, DLD. Statistical analysis: KAP. Critical revision of the manuscript for intellectual content: KAP, MV, MEE, DLD. Material support: MEE. All authors read and approved the final manuscript.
\end{abstract}

\section{Acknowledgements}

This work was supported by grants P50 AG005138 (DLD) and from Alzheimer's Association NIRG-12-242386 (DLD). We would like to thank the members of the Ehrlich, Hof, and Dickstein laboratories for technical assistance and discussion.

\section{Author details}

${ }^{1}$ Fishberg Department of Neuroscience, Icahn School of Medicine at Mount Sinai, One Gustave L. Levy Place, Box 1639, New York, NY 10029, USA. ${ }^{2}$ Friedman Brain Institute, Icahn School of Medicine at Mount Sinai, New York, NY 10029, USA. 'Department of Neurology, Icahn School of Medicine at Mount Sinai, New York, NY 10029, USA. ${ }^{4}$ Department of Pediatrics, Icahn School of Medicine at Mount Sinai, New York, NY 10029, USA

Received: 23 June 2014 Accepted: 27 August 2014

Published: 13 October 2014

\section{References}

1. Sakono M, Zako T: Amyloid oligomers: formation and toxicity of Abeta oligomers. FEBS J 2010, 277:1348-1358.

2. Koffie RM, Hyman BT, Spires-Jones TL: Alzheimer's disease: synapses gone cold. Mol Neurodegener 2011, 6:63.
3. Jacobsen JS, Wu CC, Redwine JM, Comery TA, Arias R, Bowlby M, Martone R, Morrison JH, Pangalos MN, Reinhart PH, Bloom FE: Early-onset behavioral and synaptic deficits in a mouse model of Alzheimer's disease. Proc Nat/ Acad Sci U S A 2006, 103:5161-5166.

4. Lefterov I, Fitz NF, Cronican A, Lefterov P, Staufenbiel M, Koldamova R: Memory deficits in APP23/Abca1+/- mice correlate with the level of Abeta oligomers. ASN Neuro 2009, 1(2):65-76.

5. O'Leary TP, Brown RE: Visuo-spatial learning and memory deficits on the Barnes maze in the 16-month-old APPswe/PS1dE9 mouse model of Alzheimer's disease. Behav Brain Res 2009, 201:120-127.

6. Luebke Jl, Weaver CM, Rocher AB, Rodriguez A, Crimins JL, Dickstein DL, Wearne SL, Hof PR: Dendritic vulnerability in neurodegenerative disease: insights from analyses of cortical pyramidal neurons in transgenic mouse models. Brain Struct Funct 2010, 214:181-199.

7. Giannakopoulos P, Missonnier P, Kovari E, Gold G, Michon A: Electrophysiological markers of rapid cognitive decline in mild cognitive impairment. Front Neurol Neurosci 2009, 24:39-46.

8. Akram A, Christoffel D, Rocher AB, Bouras C, Kovari E, Perl DP, Morrison JH, Herrmann FR, Haroutunian V, Giannakopoulos P, Hof PR: Stereologic estimates of total spinophilin-immunoreactive spine number in area 9 and the CA1 field: relationship with the progression of Alzheimer's disease. Neurobiol Aging 2008, 29:1296-1307.

9. Bussiere T, Friend PD, Sadeghi N, Wicinski B, Lin Gl, Bouras C, Giannakopoulos P, Robakis NK, Morrison JH, Perl DP, Hof PR: Stereologic assessment of the total cortical volume occupied by amyloid deposits and its relationship with cognitive status in aging and Alzheimer's disease. Neuroscience 2002, 112:75-91.

10. Glabe CG: Structural classification of toxic amyloid oligomers. J Biol Chem 2008, 283:29639-29643.

11. Shankar GM, Bloodgood BL, Townsend M, Walsh DM, Selkoe DJ, Sabatini BL: Natural oligomers of the Alzheimer amyloid-beta protein induce reversible synapse loss by modulating an NMDA-type glutamate receptor-dependent signaling pathway. J Neurosci 2007, 27:2866-2875.

12. Haass C, Selkoe DJ: Soluble protein oligomers in neurodegeneration: lessons from the Alzheimer's amyloid beta-peptide. Nat Rev Mol Cell Biol 2007, 8:101-112.

13. LaFerla FM, Green KN, Oddo S: Intracellular amyloid-beta in Alzheimer's disease. Nat Rev Neurosci 2007, 8:499-509.

14. LaFerla FM, Green KN: Animal models of Alzheimer disease. Cold Spring Harb Perspect Med 2012, 2:1-13.

15. Levy E, Carman MD, Fernandez-Madrid IJ, Power MD, Lieberburg I, van Duinen SG, Bots GT, Luyendijk W. Frangione B: Mutation of the Alzheimer's disease amyloid gene in hereditary cerebral hemorrhage, Dutch type. Science 1990, 248:1124-1126.

16. Kamino K, Orr HT, Payami H, Wijsman EM, Alonso ME, Pulst SM, Anderson L, O'Dahl S, Nemens E, White JA, Sadovnick AD, Ball MJ, Kaye J, Warren A, McInnis M, Antonarakis SE, Korenberg JR, Sharma V, Kukull W, Larson E, Heston LL, Martin GM, Bird TD, Schellenberg GD: Linkage and mutational analysis of familial Alzheimer disease kindreds for the APP gene region. Am J Hum Genet 1992, 51:998-1014.

17. Miravalle L, Tokuda T, Chiarle R, Giaccone G, Bugiani O, Tagliavini F, Frangione B, Ghiso J: Substitutions at codon 22 of Alzheimer's abeta peptide induce diverse conformational changes and apoptotic effects in human cerebral endothelial cells. J Biol Chem 2000, 275:27110-27116.

18. Tomiyama T, Nagata T, Shimada H, Teraoka R, Fukushima A, Kanemitsu H, Takuma H, Kuwano R, Imagawa M, Ataka S, Wada Y, Yoshioka E, Nishizaki T, Watanabe $Y$, Mori H: A new amyloid beta variant favoring oligomerization in Alzheimer's-type dementia. Ann Neurol 2008, 63:377-387.

19. Scholl M, Wall A, Thordardottir S, Ferreira D, Bogdanovic N, Langstrom B, Almkvist O, Graff $C$, Nordberg A: Low PiB PET retention in presence of pathologic CSF biomarkers in Arctic APP mutation carriers. Neurology 2012, 79:229-236.

20. Gandy S, Simon AJ, Steele JW, Lublin AL, Lah JJ, Walker LC, Levey Al, Krafft GA, Levy E, Checler F, Glabe C, Bilker WB, Abel T, Schmeidler J, Ehrlich ME: Days to criterion as an indicator of toxicity associated with human Alzheimer amyloid-beta oligomers. Ann Neurol 2010, 68:220-230.

21. Wang Z, Natte R, Berliner JA, van Duinen SG, Vinters HV: Toxicity of Dutch (E22Q) and Flemish (A21G) mutant amyloid beta proteins to human cerebral microvessel and aortic smooth muscle cells. Stroke 2000, 31:534-538.

22. Ozawa K, Tomiyama T, Maat-Schieman ML, Roos RA, Mori H: Enhanced Abeta40 deposition was associated with increased Abeta42-43 in 
cerebral vasculature with Dutch-type hereditary cerebral hemorrhage with amyloidosis (HCHWA-D). Ann N Y Acad Sci 2002, 977:149-154

23. Nishitsuji K, Tomiyama T, Ishibashi K, Kametani F, Ozawa K, Okada R, Maat-Schieman ML, Roos RA, Iwai K, Mori H: Cerebral vascular accumulation of Dutch-type Abeta42, but not wild-type Abeta42, in hereditary cerebral hemorrhage with amyloidosis, Dutch type. J Neurosci Res 2007, 85:2917-2923.

24. Harris KM, Kater SB: Dendritic spines: cellular specializations imparting both stability and flexibility to synaptic function. Annu Rev Neurosci 1994 17:341-371.

25. Carlisle HJ, Kennedy MB: Spine architecture and synaptic plasticity. Trends Neurosci 2005, 28:182-187.

26. Segal M: Dendritic spines and long-term plasticity. Nat Rev Neurosci 2005, 6:277-284.

27. Brautigam H, Steele JW, Westaway D, Fraser PE, St George-Hyslop PH, Gandy S, Hof PR, Dickstein DL: The isotropic fractionator provides evidence for differential loss of hippocampal neurons in two mouse models of Alzheimer's disease. Mol Neurodegener 2012, 7:58.

28. Tackenberg C, Ghori A, Brandt R: Thin, stubby or mushroom: spine pathology in Alzheimer's disease. Curr Alzheimer Res 2009, 6:261-268.

29. Harris KM, Jensen FE, Tsao B: Three-dimensional structure of dendritic spines and synapses in rat hippocampus (CA1) at postnatal day 15 and adult ages: implications for the maturation of synaptic physiology and long-term potentiation. J Neurosci 1992, 12:2685-2705.

30. Glenner GG, Wong CW: Alzheimer's disease: initial report of the purification and characterization of a novel cerebrovascular amyloid protein. Biochem Biophys Res Commun 1984, 120:885-890.

31. Masters CL, Simms G, Weinman NA, Multhaup G, McDonald BL, Beyreuther K: Amyloid plaque core protein in Alzheimer disease and Down syndrome. Proc Natl Acad Sci U S A 1985, 82:4245-4249.

32. Gotz J, Ittner LM, Schonrock N, Cappai R: An update on the toxicity of Abeta in Alzheimer's disease. Neuropsychiatr Dis Treat 2008, 4:1033-1042.

33. Rowe CC, Ackerman U, Browne W, Mulligan R, Pike KL, O'Keefe G, TochonDanguy H, Chan G, Berlangieri SU, Jones G, Dickinson-Rowe KL, Kung HP, Zhang W, Kung MP, Skovronsky D, Dyrks T, Holl G, Krause S, Friebe M, Lehman L, Lindemann S, Dinkelborg LM, Masters CL, Villemagne VL: Imaging of amyloid beta in Alzheimer's disease with 18F-BAY94-9172, a novel PET tracer: proof of mechanism. Lancet Neurol 2008, 7:129-135.

34. Klunk WE, Engler $\mathrm{H}$, Nordberg A, Wang Y, Blomqvist G, Holt DP, Bergstrom M, Savitcheva I, Huang GF, Estrada S, Ausén B, Debnath ML, Barletta J, Price JC, Sandell J, Lopresti BJ, Wall A, Koivisto P, Antoni G, Mathis CA, Långström $B$ : Imaging brain amyloid in Alzheimer's disease with Pittsburgh Compound-B. Ann Neurol 2004, 55:306-319.

35. Jack CR Jr, Wiste HJ, Knopman DS, Vemuri P, Mielke MM, Weigand SD, Senjem ML, Gunter JL, Lowe V, Gregg BE, Pankratz VS, Petersen RC: Rates of beta-amyloid accumulation are independent of hippocampal neurodegeneration. Neurology 2014, 82:1605-1612.

36. Sokolow S, Henkins KM, Williams IA, Vinters HV, Schmid I, Cole GM, Gylys $\mathrm{KH}$ : Isolation of synaptic terminals from Alzheimer's disease cortex. Cytometry A 2012, 81:248-254.

37. Habicht G, Haupt C, Friedrich RP, Hortschansky P, Sachse C, Meinhardt J, Wieligmann K, Gellermann GP, Brodhun M, Gotz J, Halbhuber KJ, Röcken C, Horn U, Fändrich M: Directed selection of a conformational antibody domain that prevents mature amyloid fibril formation by stabilizing Abeta protofibrils. Proc Natl Acad Sci U S A 2007, 104:19232-19237.

38. Baumketner A, Krone MG, Shea JE: Role of the familial Dutch mutation E22Q in the folding and aggregation of the 15-28 fragment of the Alzheimer amyloid-beta protein. Proc Natl Acad Sci U S A 2008 105:6027-6032.

39. Dahlgren KN, Manelli AM, Stine WB Jr, Baker LK, Krafft GA, LaDu MJ: Oligomeric and fibrillar species of amyloid-beta peptides differentially affect neuronal viability. J Biol Chem 2002, 277:32046-32053.

40. Melchor JP, Van Nostrand WE: Fibrillar amyloid beta-protein mediates the pathologic accumulation of its secreted precursor in human cerebrovascular smooth muscle cells. J Biol Chem 2000, 275:9782-9791.

41. Murakami K, Irie K, Morimoto A, Ohigashi H, Shindo M, Nagao M, Shimizu T, Shirasawa T: Neurotoxicity and physicochemical properties of Abeta mutant peptides from cerebral amyloid angiopathy: implication for the pathogenesis of cerebral amyloid angiopathy and Alzheimer's disease. J Biol Chem 2003, 278:46179-46187.

42. Herzig MC, Winkler DT, Burgermeister P, Pfeifer M, Kohler E, Schmidt SD, Danner S, Abramowski D, Sturchler-Pierrat C, Burki K, van Duinen SG, Maat-
Schieman ML, Staufenbiel M, Mathews PM, Jucker M: Abeta is targeted to the vasculature in a mouse model of hereditary cerebral hemorrhage with amyloidosis. Nat Neurosci 2004, 7:954-960.

43. Ji J, Maren S: Differential roles for hippocampal areas CA1 and CA3 in the contextual encoding and retrieval of extinguished fear. Learn Mem 2008, 15:244-251.

44. Farovik A, Dupont LM, Eichenbaum H: Distinct roles for dorsal CA3 and CA1 in memory for sequential nonspatial events. Learn Mem 2010, 17:12-17.

45. Gil N, Josman N: Memory and metamemory performance in Alzheimer's disease and healthy elderly: the Contextual Memory Test (CMT). Aging (Milano) 2001, 13:309-315.

46. Hausser M, Spruston N, Stuart GJ: Diversity and dynamics of dendritic signaling. Science 2000, 290:739-744.

47. Kampa BM, Letzkus JJ, Stuart GJ: Dendritic mechanisms controlling spike-timing-dependent synaptic plasticity. Trends Neurosci 2007 30:456-463.

48. Stuart G, Spruston N, Sakmann B, Hausser M: Action potential initiation and backpropagation in neurons of the mammalian CNS. Trends Neurosci 1997, 20:125-131.

49. Henry BI, Langlands TA, Wearne SL: Fractional cable models for spiny neuronal dendrites. Phys Rev Lett 2008, 100:128103.

50. Ferrer I, Gullotta F: Down's syndrome and Alzheimer's disease: dendritic spine counts in the hippocampus. Acta Neuropathol 1990, 79:680-685.

51. Moolman DL, Vitolo OV, Vonsattel JP, Shelanski ML: Dendrite and dendritic spine alterations in Alzheimer models. J Neurocytol 2004, 33:377-387.

52. Spires TL, Meyer-Luehmann M, Stern EA, McLean PJ, Skoch J, Nguyen PT, Bacskai BJ, Hyman BT: Dendritic spine abnormalities in amyloid precursor protein transgenic mice demonstrated by gene transfer and intravital multiphoton microscopy. J Neurosci 2005, 25:7278-7287.

53. Lacor PN, Buniel MC, Furlow PW, Clemente AS, Velasco PT, Wood M, Viola KL, Klein WL: Abeta oligomer-induced aberrations in synapse composition, shape, and density provide a molecular basis for loss of connectivity in Alzheimer's disease. J Neurosci 2007, 27:796-807.

54. Parameshwaran K, Sims C, Kanju P, Vaithianathan T, Shonesy BC, Dhanasekaran M, Bahr BA, Suppiramaniam V: Amyloid beta-peptide Abeta (1-42) but not Abeta(1-40) attenuates synaptic AMPA receptor function. Synapse 2007, 61:367-374.

55. Parameshwaran K, Dhanasekaran M, Suppiramaniam V: Amyloid beta peptides and glutamatergic synaptic dysregulation. Exp Neurol 2008, 210:7-13.

56. Nicholson DA, Yoshida R, Berry RW, Gallagher M, Geinisman Y: Reduction in size of perforated postsynaptic densities in hippocampal axospinous synapses and age-related spatial learning impairments. J Neurosci 2004, 24:7648-7653.

57. Harris KM, Weinberg RJ: Ultrastructure of synapses in the mammalian brain. Cold Spring Harb Perspect Biol 2012, 4:1-31.

58. Peters A, Palay SL, Webster H: The fine structure of the nervous system : neurons and their supporting cells. 3rd edition. New York: Oxford University Press; 1991.

59. Jones DG, Harris RJ: An analysis of contemporary morphological concepts of synaptic remodelling in the CNS: perforated synapses revisited. Rev Neurosci 1995, 6:177-219.

60. Geinisman Y: Structural synaptic modifications associated with hippocampal LTP and behavioral learning. Cereb Cortex 2000, 10:952-962

61. Isaac JT, Nicoll RA, Malenka RC: Evidence for silent synapses: implications for the expression of LTP. Neuron 1995, 15:427-434.

62. Geinisman Y, Ganeshina O, Yoshida R, Berry RW, Disterhoft JF, Gallagher M: Aging, spatial learning, and total synapse number in the rat $C A 1$ stratum radiatum. Neurobiol Aging 2004, 25:407-416.

63. Ganeshina O, Berry RW, Petralia RS, Nicholson DA, Geinisman Y: Differences in the expression of AMPA and NMDA receptors between axospinous perforated and nonperforated synapses are related to the configuration and size of postsynaptic densities. J Comp Neurol 2004, 468:86-95.

64. Nusser Z, Lujan R, Laube G, Roberts JD, Molnar E, Somogyi P: Cell type and pathway dependence of synaptic AMPA receptor number and variability in the hippocampus. Neuron 1998, 21:545-559.

65. Petralia RS, Esteban JA, Wang YX, Partridge JG, Zhao HM, Wenthold RJ, Malinow R: Selective acquisition of AMPA receptors over postnatal development suggests a molecular basis for silent synapses. Nat Neurosci 1999, 2:31-36. 
66. Racca C, Stephenson FA, Streit P, Roberts JD, Somogyi P: NMDA receptor content of synapses in stratum radiatum of the hippocampal CA1 area. J Neurosci 2000, 20:2512-2522.

67. Takumi Y, Ramirez-Leon V, Laake P, Rinvik E, Ottersen OP: Different modes of expression of AMPA and NMDA receptors in hippocampal synapses. Nat Neurosci 1999, 2:618-624.

68. Gu Z, Liu W, Yan Z: \{beta\}-Amyloid impairs AMPA receptor trafficking and function by reducing $\mathrm{Ca} 2+/$ calmodulin-dependent protein kinase II synaptic distribution. J Biol Chem 2009, 284:10639-10649.

69. Poncer JC, Esteban JA, Malinow R: Multiple mechanisms for the potentiation of AMPA receptor-mediated transmission by alpha-Ca2 +/calmodulin-dependent protein kinase II. J Neurosci 2002, 22:4406-4411.

70. Hayashi Y, Shi SH, Esteban JA, Piccini A, Poncer JC, Malinow R: Driving AMPA receptors into synapses by LTP and CaMKII: requirement for GluR1 and PDZ domain interaction. Science 2000, 287:2262-2267.

71. Hefti F, Goure WF, Jerecic J, Iverson KS, Walicke PA, Krafft GA: The case for soluble Abeta oligomers as a drug target in Alzheimer's disease. Trends Pharmacol Sci 2013, 34:261-266.

72. Pozueta J, Lefort R, Shelanski ML: Synaptic changes in Alzheimer's disease and its models. Neuroscience 2013, 251:51-65.

73. Chishti MA, Yang DS, Janus C, Phinney AL, Horne P, Pearson J, Strome R, Zuker N, Loukides J, French J, Turner S, Lozza G, Grilli M, Kunicki S, Morissette C, Paquette J, Gervais F, Bergeron C, Fraser PE, Carlson GA, George-Hyslop PS, Westaway D: Early-onset amyloid deposition and cognitive deficits in transgenic mice expressing a double mutant form of amyloid precursor protein 695. J Biol Chem 2001, 276:21562-21570.

74. Dudal S, Krzywkowski P, Paquette J, Morissette C, Lacombe D, Tremblay P, Gervais F: Inflammation occurs early during the Abeta deposition process in TgCRND8 mice. Neurobiol Aging 2004, 25:861-871.

75. Steele JW, Brautigam H, Short JA, Sowa A, Shi M, Yadav A, Weaver CM, Westaway D, Fraser PE, St George-Hyslop PH, Gandy S, Hof PR, Dickstein DL: Early fear memory defects are associated with altered synaptic plasticity and molecular architecture in the TgCRND8 Alzheimer's disease mouse model. J Comp Neurol 2014, 522:2319-2335.

76. Dickstein DL, Brautigam H, Stockton SD Jr, Schmeidler J, Hof PR: Changes in dendritic complexity and spine morphology in transgenic mice expressing human wild-type tau. Brain Struct Funct 2010, 214:161-179.

77. Olichney JM, Hansen LA, Galasko D, Saitoh T, Hofstetter CR, Katzman R, Thal $\sqcup$ : The apolipoprotein E epsilon 4 allele is associated with increased neuritic plaques and cerebral amyloid angiopathy in Alzheimer's disease and Lewy body variant. Neurology 1996, 47:190-196.

78. Tyan SH, Shih AY, Walsh JJ, Maruyama H, Sarsoza F, Ku L, Eggert S, Hof PR, Koo EH, Dickstein DL: Amyloid precursor protein (APP) regulates synaptic structure and function. Mol Cell Neurosci 2012, 51:43-52.

79. Sholl DA: Dendritic organization in the neurons of the visual and motor cortices of the cat. J Anat 1953, 87:387-406.

80. Radley JJ, Rocher AB, Rodriguez A, Ehlenberger DB, Dammann M, McEwen BS, Morrison JH, Wearne SL, Hof PR: Repeated stress alters dendritic spine morphology in the rat medial prefrontal cortex. J Comp Neurol 2008, 507:1141-1150.

81. Radley JJ, Rocher AB, Miller M, Janssen WG, Liston C, Hof PR, McEwen BS, Morrison $\mathrm{JH}$ : Repeated stress induces dendritic spine loss in the rat medial prefrontal cortex. Cereb Cortex 2006, 16:313-320.

82. Wearne SL, Rodriguez A, Ehlenberger DB, Rocher AB, Henderson SC, Hof PR: New techniques for imaging, digitization and analysis of three-dimensional neural morphology on multiple scales. Neuroscience 2005, 136:661-680.

83. Rodriguez A, Ehlenberger DB, Hof PR, Wearne SL: Rayburst sampling, an algorithm for automated three-dimensional shape analysis from laser scanning microscopy images. Nat Protoc 2006, 1:2152-2161.

84. Rodriguez A, Ehlenberger DB, Dickstein DL, Hof PR, Wearne SL: Automated three-dimensional detection and shape classification of dendritic spines from fluorescence microscopy images. PLoS One 2008, 3:e1997.

85. Bloss EB, Puri R, Yuk F, Punsoni M, Hara Y, Janssen WG, McEwen BS, Morrison JH: Morphological and molecular changes in aging rat prelimbic prefrontal cortical synapses. Neurobiol Aging 2013, 34:200-210.

86. Janssen WG, Vissavaijhala $P$, Andrews $G$, Moran $T$, Hof PR, Morrison JH: Cellular and synaptic distribution of NR2A and NR2B in macaque monkey and rat hippocampus as visualized with subunit-specific monoclonal antibodies. Exp Neurol 2005, 191(Suppl 1):S28-44.

87. Dumitriu D, Hao J, Hara Y, Kaufmann J, Janssen WG, Lou W, Rapp PR, Morrison $\mathrm{JH}$ : Selective changes in thin spine density and morphology in monkey prefrontal cortex correlate with aging-related cognitive impairment. J Neurosci 2010, 30:7507-7515.

88. Hara Y, Rapp PR, Morrison JH: Neuronal and morphological bases of cognitive decline in aged rhesus monkeys. Age (Dordr) 2012, 34:1051-1073.

89. Holtmaat AJ, Trachtenberg JT, Wilbrecht L, Shepherd GM, Zhang X, Knott GW, Svoboda K: Transient and persistent dendritic spines in the neocortex in vivo. Neuron 2005, 45:279-291.

90. Kasai H, Matsuzaki M, Noguchi J, Yasumatsu N, Nakahara H: Structurestability-function relationships of dendritic spines. Trends Neurosci 2003, 26:360-368.

doi:10.1186/1750-1326-9-41

Cite this article as: Price et al: Altered synaptic structure in the hippocampus in a mouse model of Alzheimer's disease with soluble amyloid- $\beta$ oligomers and no plaque pathology. Molecular Neurodegeneration 2014 9:41.

\section{Submit your next manuscript to BioMed Central and take full advantage of:}

- Convenient online submission

- Thorough peer review

- No space constraints or color figure charges

- Immediate publication on acceptance

- Inclusion in PubMed, CAS, Scopus and Google Scholar

- Research which is freely available for redistribution

Submit your manuscript at www.biomedcentral.com/submit
C) Biomed Central 